\title{
PERLINDUNGAN HUKUM BAGI PEMEGANG SERTIFIKAT HAK MILIK ATAS TANAH DALAM KETENTUAN PASAL 32 AYAT (2) PP No. 24 TAHUN 1997
}

\author{
Oleh \\ Putu Ade Harriestha Martana \\ Program Studi Magister (S2) Ilmu Hukum \\ Program Pascasarjana Universitas Udayana
}

\begin{abstract}
The title of this study is "legal protection for land ownership right certificate holder according to Article 32 clause (2) Government Regulation Number 24 Year 1997”. There is a contradiction between the negative publication system which is adopted in Indonesian land registration system and the indefeasable title that is given after the certificate is published for more than five years according to Article 32 clause (2) Government Regulation Number 24 Year 1997 about Land Registration. Therefore some issues are occured, which is the legal certainty and legal protection of the land ownership right certificate holder after the five years period according to Article 32 clause (2) Government Regulation Number 24 Year 1997.

The research method used in this study is normative legal research focusing on investigation of legislature as the primary legal material and supported with the legal doctrine as secondary legal material. The approaching methods used is legal concepts approach and statute approach.

From the legal material research can be concluded that in normative basis the aim of article 32 clause (2) Government Regulation Number 24 year 1997 is to give a legal protection and legal certainty, but in the process the article is contradictory to the negative publication system and the clauses in the article itself is contradictory, therefore it does not give adequate legal protection and legal certainty for the holder of the land ownership right certificate after the five years period.
\end{abstract}

Key words : land registration, land ownership right certificate, legal protection, legal certainty. 


\section{Pendahuluan}

\subsection{Latar Belakang}

Hak milik atas tanah menurut Pasal 20 ayat (1) Undang-Undang Nomor 5 Tahun 1960 tentang Peraturan Dasar Pokok-Pokok Agraria yang selanjutnya disebut sebagai Undang Undang Pokok Agraria (UUPA) merupakan hak atas tanah yang bersifat turun-temurun, terkuat dan terpenuh yang dapat dipunyai orang atas tanah. Turun-temurun disini diartikan sebagai hak yang bisa diturunkan kepada ahli waris, terkuat dalam hubungannya dengan hak atas tanah yang lain, dan terpenuh dalam hal kewenangan yang ddimiliki pemegang haknya. Menurut Pasal 16 ayat (1) huruf a UUPA salah satu hak atas tanah yang diakui adalah hak milik.

Dalam sejarahnya sebelum berlakunya UUPA terdapat dualisme hukum agraria di Indonesia. Dualisme dalam hukum agraria tersebut lebih merugikan golongan masyarakat pribumi, karena hukum adat yang mengatur tanah-tanah dengan hak adat merupakan hukum yang tidak tertulis sedangkan di lain pihak atas tanahtanah dengan hak barat diatur dengan hukum barat yang sudah tertulis. Pendaftaran bagi tanah-tanah yang tunduk pada hukum barat bertujuan untuk memberikan jaminan kepastian hukum yang dikenal sebagai Rechts Cadaster atau Legal Cadaster. Sedangkan untuk tanah hak adat walaupun ada pendaftaran namun tidak bertujuan untuk memberikan jaminan kepastian hukum tetapi lebih kepada pendataan administratif terutamanya berkaitan dengan pembayaran pajak yang dikenal sebagai Fiscaal Cadaster, yang menghasilkan suatu tanda bukti pembayaran pajak atas tanah yang mengakibatkan tidak adanya tanda bukti tertulis sebagai tanda bukti hak atas tanah berupa sertifikat sehingga tidak memberikan kepastian hukum dan perlindungan hukum atas pelaksanaan hak tersebut.

Ketimpangan inilah yang menjadi salah satu alasan dibentuknya UUPA, sebagaimana disebutkan dalam konsideran menimbang dan berpendapat UUPA. Dengan diberlakukannya UUPA maka secara formal diinstruksikan kepada pemerintah agar di seluruh wilayah Indonesia diadakan pendaftaran tanah 
yang bersifat rechts kadaster, artinya yang bertujuan menjamin kepastian hukum. Hal ini dapat kita lihat pada Pasal 19 ayat (1) UUPA yang mengamanatkan pemerintah untuk menyelenggarakan pendaftaran tanah demi terjaminnya kepastian hukum atas tanah-tanah di seluruh wilayah Republik Indonesia, dan juga mengamanatkan pembentukan suatu peraturan pemerintah untuk pelaksanaanya. Kewajiban dalam hal pendaftaran ini tidak hanya dibebankan kepada pemerintah sebagai penyelenggara pendaftaran saja tetapi juga bagi pemegang haknya untuk melakukan pendaftaran atas kesadarannya sendiri. Kewajiban bagi pemegang haknya tersebut ditegaskan dalam Pasal 23 UUPA.

Pendaftaran tanah diatur dalam

Peraturan Pemerintah Nomor 24 Tahun 1997 tentang Pendaftaran Tanah (selanjutnya disebut PP No. 24/1997) dan Ketentuan Pelaksanaanya yaitu Peraturan Menteri Negara Agraria / Kepala Badan Pertanahan Nasional (PMNA/KBPN) Nomor 3 Tahun 1997 sebagaimana telah dirubah dengan Peraturan KBPN No. 8 Tahun 2012.
Tujuan pendaftaran tanah tersebut sesuai dengan Pasal 3 huruf a PP No.24/1997 adalah "untuk memberikan kepastian hukum dan perlindungan hukum...”. Untuk mewujudkannya menurut Pasal 4 ayat (1) PP No.24/1997 diterbitkanlah sertifikat hak atas tanah bagi pemegang hak yang bersangkutan. Sertifikat tersebut berfungsi sebagai surat tanda bukti hak yang berlaku sebagai alat pembuktian yang kuat. Dengan syarat sesuai dengan data fisik dan data yuridis yang terdapat dalam buku tanah dan surat ukur yang bersangkutan.

Dalam pasal-pasal tersebut tujuan dari pendaftaran tanah adalah untuk memberikan surat tanda bukti hak yang kuat. Hal ini menunjukkan pada kita semua bahwa UUPA menganut sistem pendaftaran yang disebut dengan registration of title stelsel negatif yang mengandung unsur positif. ${ }^{1}$ Ia berlaku sebagai alat pembuktian yang kuat, jadi sertifikat tersebut masih dapat digugat keabsahannya, dalam hal ini yang berlaku adalah stelsel negatif.

1 Kartini Muljadi dan Gunawan Widjaja, 2004, Hak-Hak Atas Tanah, Prenada Media, Jakarta, hal. 89. 
Namun dalam Pasal 32 ayat 2

PP No. 24/1997 disebutkan :

Dalam hal atas suatu bidang tanah sudah diterbitkan sertifikat secara sah atas nama orang atau badan hukum yang memperoleh tanah tersebut dengan itikad baik dan secara nyata menguasainya, maka pihak lain yang merasa mempunyai hak atas tanah itu tidak dapat lagi menuntut pelaksanaan hak tersebut apabila dalam waktu 5 (lima) tahun sejak diterbitkannya sertifikat itu tidak mengajukan keberatan secara tertulis kepada pemegang sertifikat dan Kepala Kantor Pertanahan yang bersangkutan ataupun tidak mengajukan gugatan ke Pengadilan mengenai penguasaan tanah atau penerbitan sertifikat tersebut.

Menurut ketentuan ini dalam jangka waktu lima tahun jika tidak ada tindakan hukum oleh pihak lain atas sertifikat tersebut, maka pemegang sertifikat tersebut tidak dapat lagi diganggu gugat keabsahannya.

Dalam kenyataannya terdapat gugatan atas sertifikat yang telah melewati batas waktu lima tahun tersebut yang diterima. Hal ini tentunya bertentangan dengan peraturan perundang-undangan yang berlaku dalam hal ini Pasal 32 ayat 2 PP No. 24/1997 yang berlaku sebagai hukum positif. Sehingga hal ini dapat menimbulkan kerancuan dalam penerapan hukum dan juga menyebabkan tidak adanya kepastian dan perlindungan hukum bagi pemegang sertifikat hak milik atas tanah.

\subsection{Rumusan Masalah}

Maka berdasarkan latar belakang yang telah dipaparkan, dalam penelitian ini akan dikaji permasalahan yang menjadi fokus sebagai berikut :

1. Bagaimanakah kepastian hukum sertifikat hak milik atas tanah, setelah jangka waktu lima tahun sesuai dengan Pasal 32 ayat (2) PP No. 24/1997 tentang pendaftaran Tanah.

2. Bagaimanakah perlindungan hukum bagi pemegang sertifikat hak milik atas tanah setelah jangka waktu lima tahun sesuai dengan Pasal 32 ayat (2) PP No. 24/1997 tentang pendaftaran Tanah.

\subsection{Tujuan Penulisan}

1. Untuk mengkaji kepastian hukum sertifikat hak milik atas 
tanah dikaitkan dengan Pasal 32 ayat 2 PP No. 24/1997, berkaitan dengan lewatnya batas waktu lima tahun dalam peraturan tersebut.

2. Untuk mengkaji lebih dalam tentang perlindungan hukum bagi pemegang sertifikat hak milik atas tanah berkaitan dengan Pasal 32 ayat 2 PP No. 24/1997 tentang pendaftaran Tanah.

\section{Metode Penelitian}

Penelitian dalam penyusunan jurnal ilmiah ini merupakan jenis penelitian normatif, yang bertujuan mengumpulkan bahan hukum dan informasi dengan bantuan macammacam material yang terdapat di perpustakaan. $^{2}$

Dalam penelitian hukum dikenal ada beberapa metode pendekatan, pendekatan yang digunakan dalam penelitian ini adalah pendekatan konsep hukum / konseptual dan pendekatan perundang-undangan.

${ }^{2}$ Kartini Kartono, 1996, Pengantar Metodologi Riset Sosial, Mandar Maju, Bandung, hal. 33.

\section{Hasil dan Pembahasan}

\subsection{Tinjauan Umum Tentang Pendaftaran Tanah}

a. Dasar Timbulnya Hak Milik Atas Tanah

Pasal 33 ayat (3) UndangUndang Dasar Negara Republik Indonesia Tahun 1945 (selanjutnya disebut UUD NRI Tahun 1945) menyatakan "bumi air dan kekayaan alam yang terkandung di dalamnya dikuasai oleh negara dan dipergunakan untuk sebesar-besar kemakmuran rakyat.

Pasal tersebut merupakan norma dasar (landasan konstitusional) dari pembentukan hukum agraria di Indonesia, yang kemudian dijabarkan dalam UUPA. Dalam Pasal 33 ayat (3) UUD NRI Tahun 1945 tersebut terkandung konsepsi hak menguasai dari negara, yang kemudian menjadi dasar dalam pembentukan UUPA.

$$
\text { Pasal } 2 \text { ayat (1) UUPA }
$$

menyebutkan:

Atas dasar ketentuan dalam pasal 33 ayat (3) Undangundang Dasar dan hal-hal sebagai yang dimaksud dalam pasal 1, bumi, air dan ruang angkasa, termasuk kekayaan alam yang terkandung didalamnya itu pada tingkatan 
tertinggi dikuasai oleh Negara....

Dalam Pasal 2 ayat (2) UUPA dirumuskan secara formal mengenai hak mengusai dari negara, yang diantaranya adalah untuk mengatur dan menyelenggarakan peruntukan, penggunaan, persediaan dan pemeliharaan bumi, air dan ruang angkasa.

Pasal 4 ayat (1) UUPA menyebutkan:

Atas dasar hak menguasai dari negara sebagaimana yang dimaksud Pasal 2 ditentukan adanya macam-macam hak atas permukaan bumi, yang disebut tanah.....

Macam-macam hak tersebut salah satunya adalah hak milik atas tanah (Pasal 16 ayat (1) UUPA).

\section{b. Dasar Hukum Pendaftaran Tanah}

Berdasarkan Pasal 19 ayat (1) UUPA, terkait dengan Pendaftaran tanah diamanatkan pembentukan suatu peraturan pemerintah untuk mengaturnya. Sehingga ditetapkanlah Peraturan Pemerintah No. 10 Tahun 1961 tentang Pendaftaran Tanah, yang kemudian diperbaharui dengan
Peraturan Pemerintah No. 24 Tahun 1997.

Berdasarkan Pasal 19 ayat (1) UUPA jo. Pasal 1 angka 1 PP No. 24 Tahun 1997 penyelenggaraan pendaftaran atas tanah dilaksanakan oleh pemerintah, kewenangan ini bersumber pada Pasal 33 ayat (3) UUD NRI Tahun 1945. Penjabaran pasal ini secara khusus dalam UUPA terdapat pada Pasal 2 ayat (1) sebagai dasar hak menguasai negara atas tanah. Hak menguasai dari negara atas tanah tersebut dijabarkan dengan lebih terperinci pada Pasal 2 ayat (2) UUPA, berkaitan dengan kewenangan untuk melakukan pendaftaran tanah terdapat pada Pasal 2 ayat (2) huruf c yang menyatakan negara berwewenang untuk:

menentukan dan mengatur hubungan-hubungan hukum antara orang-orang dan perbuatan-perbuatan hukum yang mengenai bumi, air dan ruang angkasa.

Termasuk dalam pasal ini adalah wewenang untuk menentukan dan mengatur pendaftaran atas tanah di wilayah Republik Indonesia.

Dalam Pasal 5 ayat PP No. 24/ 1997 disebutkan bahwa "pendaftaran tanah diselenggarakan oleh Badan 
Pertanahan Nasional" (BPN). Pengaturannya lebih lanjut dengan pengesahan Keppres No. 26 Tahun 1988 tentang BPN yang kemudian dirubah dengan Keppres No. 154 Tahun 1999. Dan karena dipandang perlu untuk mengatur kembali Badan Pertanahan Nasional dengan Peraturan Presiden, maka ditetapkanlah Perpres No. 10 Tahun 2006 tentang BPN yang kemudian dirubah dengan Perpres No. 85 Tahun 2012.

\section{c. Asas, Tujuan dan Sistem Pendaftaran Tanah}

Pendaftaran tanah tentunya dilatarbelakangi suatu asas atau prinsip dasar sebagai pedoman dalam perumusan peraturan dan pelaksanaannya. Dalam Pasal 2 PP No. 24 Tahun1997 tentang Pendaftaran Tanah disebutkan bahwa pelaksanaan Pendaftaran tanah berdasarkan asas sederhana, aman, terjangkau, mutakhir dan terbuka.

Asas sederhana dalam pendaftaran tanah dimaksudkan agar pihak-pihak yang berkepentingan, dengan mudah memahami ketentuanketentuan maupun prosedur pendaftaran tanah.
Asas aman dimaksudkan untuk memberikan rasa aman bagi pemegang hak. Sehingga dalam penyelenggaraannya harus dilakukan secara teliti dan cermat yang berakibat hasilnya sesuai dengan kenyataan yang ada sehingga memenuhi unsur kepastian hukum.

Asas terjangkau diperlukan karena kemampuan dan kebutuhan pihak ekonomi lemah tetap harus diperhatikan.

Asas mutakhir disini mengenai kelengkapan sumber daya yang sesuai perkembangan dan data yang juga harus sesuai dengan keadaan terakhir. Sehingga harus menggunakan kelengkapan yang memadai dalam pelaksanaannya dan data pendaftaran tanah harus dipelihara sehingga data tersebut aktual. Agar hal tersebut dapat terwujud, diwajibkan untuk menyelenggarakan pemutakhiran /pembaharuan data sehingga sesuai dengan kenyataan yang ada, hal ini berkaitan dengan asas terbuka.

Asas terbuka menuntut agar data pendaftaran tanah yang benar dapat diakses oleh pihak yang memerlukan. Dalam hal ini informasi 
tersebut harus dapat dipertanggung jawabkan kebenarannya.

Selain itu dalam pendaftaran tanah ini juga menggunakan asas publisitas dan spesialitas dalam pendaftaran tanah. Asas publisitas menentukan bahwa dengan adanya pendaftaran hak atas tanah secara tidak langsung merupakan pengumuman terhadap adanya hubungan hukum antara tanah dan pemegang haknya. Dengan adanya pegumuman ini pihak lain dianggap mengetahui. Dan asas spesialitas, yang menentukan adanya hubungan hukum antara subyek hak milik yang jelas dan obyek hak milik tertentu yang jelas lokasi, luas dan jenis haknya. ${ }^{3}$ Tujuan dari digunakannya asas tersebut ialah agar dapat mengikat pihak lain dan memberikan kepastian hukum kepada pemegang haknya.

Tujuan dari pendaftaran tanah menurut Pasal 3 PP No. 24 Tahun 1997 adalah :

a. untuk memberikan kepastian hukum dan perlindungan

Salim HS. H., 2008 ,
Perkembangan Hukum Jaminan di Indonesia, Rajawali Pers, Jakarta, hal. 9. hukum kepada pemegang hak...;

b. untuk menyediakan informasi kepada pihak-pihak yang berkepentingan...;

c. untuk terselenggaranya tertib administrasi pertanahan....

Pemberian jaminan kepastian hukum dan perlindungan hukum di bidang agraria memerlukan adanya peraturan perundang-undangan yang jelas rumusannya sehingga dapat dilaksanakannya secara efektif.

Pelaksanaan pendaftaran tanah untuk menghasilkan sertifikat sebagai surat tanda bukti hak atas tanah memerlukan suatu sistem pendaftaran tanah. Sistem pendaftaran tanah dapat dibedakan ke dalam: ${ }^{4}$

a. registration of deeds (sistem pendaftaran akta), yang dilakukan dalam bentuk pendaftaran aktanya, yang berisi perbuatan hukum yang menerbitkan hak atas tanah atau pembebanannya. Setiap kali ada perubahan, maka akan dibuatkan akta perubahan, yang merupakan bukti satusatunya dari terjadinya perubahan tersebut.

b. registration of title (sistem pendaftaran hak), yang mendaftarkan titel hak yang diperoleh. Akta yang dibuat untuk menciptakan hak atau

4 Kartini Muljadi dan Gunawan Widjaja, Loc. Cit., hal. 89. 
pembebanannya hanya dipergunakan sebagai rujukan pendaftaran haknya tersebut.

Pelaksanaan pendaftaran tanah di Indonesia lebih condong kepada sistem pendaftaran akta. Hal ini terlihat pada Pasal 19 ayat (2) huruf c UUPA jo. Pasal 1 angka 20 PP 24 Tahun 1997, bahwa pendaftaran meliputi pemberian surat tanda bukti hak berupa sertifikat. Jadi ada pemberian surat tanda bukti hak berupa sertifikat, dimana timbulnya hak dan peralihannya didaftarkan dalam buku tanah dan sertifikat sebagai salinannya bersama surat ukur. Jika ada perubahan tidak diterbitkan sertifikat baru melainkan dicatat pada ruang / kolom mutasi buku tanah tersebut.

Untuk menilai kekuatan hukum dari sertifikat yang dihasilkan dari pendaftaran hak atas tanah dan sejauh mana masyarakat dapat mempercayai data yang terdapat dalam sertifikat, dikenal adanya sistem publikasi dalam pendaftaran tanah. Yang pertama adalah sistem publikasi / stelsel positif dan sistem publikasi / stelsel negatif. Dalam sistem publikasi positif pemegang sertifikat hak atas tanah dilindungi, dalam sistem publikasi negatif masih dimungkinkan proses pembuktian lain selain melalui sertifikat hak atas tanah. $^{5}$

Dalam Pasal 19 ayat (2) huruf c UUPA disebutkan adanya "pemberian surat-surat tanda bukti hak yang berlaku sebagai alat pembuktian yang kuat" sebagai bagian dari proses pendaftaran. Kuat disini bukanlah mutlak sehingga pendaftaran tanah tidak menganut sistem publikasi positif dimana kebenaran data yang disajikan dijamin oleh penerbit dalam hal ini pemerintah, namun yang dianut adalah sistem publikasi negatif.

Berdasarkan hal tersebut di atas pendaftaran tanah dilaksanakan dengan menggunakan sistem publikasi negatif namun yang bertendensi positif, karena dalam pendaftaran tersebut juga meliputi pemberian sertifikat yang merupakan alat pembuktian yang bersifat kuat.

\subsection{Tinjauan Umum Tentang Pasal 32 ayat (2) PP No. 24/1997}

PP No. 24/1997 dimaksudkan sebagai penyempurnaan dari peraturan

5 Kartini Muljadi dan Gunawan Widjaja, Op. Cit., hal. 90. 
sebelumnya, yakni PP No. 10 Tahun 1961. Untuk mengakomodasi perbaikan dalam bidang pendaftaran tanah tersebut, Peraturan Pemerintah ini memperjelas dan mempertegas beberapa ketentuan dasar dari UUPA.

Penegasan yang penting mengenai sejauh mana kekuatan pembuktian sertifikat sebagaimana diatur dalam Pasal 32 ayat (1) PP No. 24 Tahun 1997, bahwa sertifikat tersebut dinyatakan “...berlaku sebagai alat pembuktian yang kuat mengenai data fisik dan data yuridis yang termuat di dalamnya...". Dapat disimpulkan bahwa selama belum dibuktikan sebaliknya maka sertifikat tersebut harus dianggap benar dalam kaitannya sebagai alat bukti kepemilikan termasuk di depan pengadilan. Namun karena sistem publikasi yang di anut adalah negatif maka untuk mewujudkan tujuan pendaftaran tanah tersebut sebagaimana disebutkan dalam Pasal 3 huruf a PP No. 24/1997 yaitu: "untuk memberikan kepastian hukum dan perlindungan hukum kepada pemegang hak atas suatu bidang tanah..." menjadi sulit.
Untuk mencapai tujuan pendaftaran tanah tersebut maka dibuatlah aturan mengenai jangka waktu pengajuan gugatan, dimana setelah jangka waktu tertentu maka hak milik atas tanah yang dimiliki seseorang tidak dapat diganggu gugat oleh pihak lain yang merasa berhak atas tanah tersebut. Sebagaimana disebutkan dalam Pasal 32 ayat (2) PP No. 24 Tahun 1997, bahwa jika sertifikat telah diterbitkan secara sah dan pemegang sertifikat memperoleh tanah tersebut dengan itikad baik dan secara nyata menguasainya maka pihak lain yang merasa memiliki hak atas tanah tersebut tidak dapat menuntut pelaksanaan haknya tersebut jika dalam jangka waktu lima tahun tidak mengajukan gugatan atas penguasaan atau penerbitan sertifikat tersebut.

Pasal 32 ayat (2) dalam PP No. 24 Tahun 1997 ini merupakan cara untuk menyiasati kelemahan dalam sistem publikasi negatif dari pendaftaran tanah dalam hal kepastian dan perlindungan hukum.

Oleh pembentuk undangundang Pasal tersebut dinyatakan sebagai perwujudan lembaga 
rechtsverwwerking yang berlaku dalam hukum adat. Rechtsverwerking ini adalah lembaga yang dengan lampaunya waktu, di mana: ${ }^{6}$

1. Orang yang telah memegang hak atas tanahnya menjadi kehilangan haknya karena selama waktu tertentu tidak mengusahakan hak atas tanah tersebut;

2. Orang yang dengan itikad baik telah menguasai dan memanfaatkan bidang tanah tersebut, berhak untuk memperoleh hak atas tanah yang telah dimanfaaatkan olehnya tersebut.

Konsideran berpendapat

UUPA huruf a menyatakan perlu adanya hukum agraria nasional, yang berdasar atas hukum adat tentang tanah, sehingga dibentuklah UUPA yang dalam Pasal 5 yang menyatakan "hukum agraria yang berlaku atas bumi, air dan ruang angkasa ialah hukum adat...".

\section{Dalam Penjelasan Umum II} angka 4 UUPA menyatakan bahwa fungsi sosial berhubungan dengan kewajiban untuk memelihara tanah, yaitu menambah kesuburannya dan mencegah kerusakannya. Dalam hukum adat di samping hak untuk

6 Kartini Muljadi dan Gunawan Widjaja, Op. Cit., hal. 83-84. menguasai dan mengolah tanah persekutuan juga terdapat kewajiban untuk memeliharanya. Hukum adat selain memberi kewenangan menguasai dan memanfaatkan tanah juga memberi kewajiban sosial tertentu yaitu menggunakan atau mengerjakan tanahnya yang harus dilakukan secara terus menerus agar hubungan hukum antara dirinya dengan tanah semakin menguat. ${ }^{7}$

Jadi tujuan Pasal 32 ayat (2) PP No. 24 Tahun 1997 bertujuan untuk mengatasi kelemahan sistem publikasi negatif, dengan tetap memperhatikan keseimbangan perlindungan hukum antara pihak yang merupakan pemilik tanah sebenarnya yang menguasai dan menggunakan tanahnya dengan baik dan pihak yang memperolehnya dan menguasainya dengan itikad baik dari pihak lain.

Namun karena sulitnya mengakomodir kedua tujuan tersebut berakibat adanya ketidakjelasan dalam rumusan Pasal tersebut dan bertentangan dengan sistem publikasi

7 Willy Laluyan, et.al., 1982, Pertanahan Dalam Era Pembangunan Indonesia, Departemen Penerangan RI, Jakarta, hal. 18. 
negatif yang digunakan dalam pendaftaran tanah. Bahwa jika sertifikat hak atas tanah telah diterbitkan setelah lima tahun, maka sertifikat tersebut tidak dapat diganggu gugat lagi. Namun dalam pasal tersebut juga disebutkan bahwa sertifikat tersebut masih dapat digugat jika tidak memenuhi syarat diterbitkan secara sah, diperoleh dengan itikad baik dan secara nyata dikuasai, dan sejak diterbitkannya sertifikat tidak ada keberatan ataupun gugatan mengenai penguasaan tanah atau penerbitan sertifikat tersebut dalam jangka waktu lima tahun.

Walaupun telah lewat jangka waktu lima tahun jika yang menjadi dasar gugatan adalah mengenai masalah keabsahan penerbitan sertifikat, maka pembatasan waktu lima tahun tersebut dikesampingkan. Karena harus dibuktikan kebenaran dalil penggugat mengenai tidak sahnya penerbitan sertifikat tersebut.

Tipe penyelesaian berkaitan dengan asas preferensi hukum yaitu; pengingkaran (disavowal), reinterpretasi, pembatalan (invalidation) dan pemulihan (remedy). ${ }^{8}$ Dalam hal gugatan mengenai keabsahan penerbitan sertifikat hak milik atas tanah adalah melalui Pengadilan Tata Usaha Negara, sebab sertifikat tersebut merupakan Keputusan Tata Usaha Negara. Dalam kasus gugatan mengenai keabsahan sertifikat hak milik hakim PTUN dapat mengenyampingkan norma Pasal 32 ayat (2) PP No. 24 tahun 1997 yang memberikan tenggang waktu mengajukan gugatan. Keputusan pengenyampingan suatu norma didapat dengan melakukan reinterpretasi, yaitu; dimana norma preferensi diinterpretasi dan kemudian menerapkan norma tersebut dengan mengenyampingkan norma yang lain. ${ }^{9}$ Dapat juga melalui pembatalan praktikal, yaitu; tidak menerapkan norma tersebut dalam kasus konkrit yang dikenal dalam praktek dikenal sebagai mengenyampingkan. ${ }^{10}$

Secara konkrit dapat terlihat dari Putusan Pengadilan Tata Usaha

${ }^{8}$ Philipus M. Hadjon dan Tatiek Sri Djatmiati, 2009, Argumentasi Hukum, Gadjah Mada University Press, Cetakan Keempat, hal. 31 .

\footnotetext{
${ }^{9} \mathrm{Ibid}$, hal. 32.

${ }^{10}$ Ibid.
} 
Negara (PTUN) Bandung No.64/G/2010/PTUN-BDG tertanggal 22 Maret 2011, yang menyatakan batal 62 sertifikat walaupun sertifikat tersebut telah diterbitkan lebih dari lima tahun, diantaranya:

1. Sertifikat Hak Milik Nomor : 911/Kelurahan Cinangka diterbitkan tangga 19-4-1980, Gambar Situasi Nomor : 1446/1979 tanggal 26- 4- 1979

2. Sertifikat Hak Milik Nomor : 912/Kelurahan Cinangka,

Diterbitkan tangga 19-4-1980, Gambar Situasi Nomor : 1447/1979, tanggal 26-4-1979;

3. Sertifikat Hak Milik Nomor : 913/Kelurahan Cinangka, Diterbitkan tanggal 9-4-1980, Gambar Situasi Nomor : 1448/1979, tanggal 26-4-1979.

\subsection{Konsep Kepastian Hukum}

Kepastian hukum merupakan hal mutlak dalam negara hukum, dimana setiap tindak pemerintahan harus didasarkan atas hukum. Konsep ini terdapat baik dalam konsep rechstaat yaitu adanya asas legalitas, maupun dalam konsep the rule of law yaitu adanya supremasi hukum. menurut J.M. Otto kepastian hukum adalah : ${ }^{11}$

1. tersedia aturan-aturan hukum yang jelas, konsisten dan mudah diperoleh (accessible), diterbitkan oleh atau diakui karena (kekuasaan) negara;

2. bahwa instansi-instansi penguasa (pemerintahan) menerapkan aturan-aturan hukum tersebut secara konsisten juga tunduk dan taat terhadapnya;

3. bahwa pada prinsipnya bagian terbesar atau mayoritas warga negara menyetujui muatan isi dankarena itu menyesuaikan perilaku mereka terhadap aturan-aturan tersebut;

4. bahwa hakim-hakim (peradilan) yang mandiri dan tidak berpihak menerapkan aturan-aturan hukum tersebut secara konsisten sewaktu mereka menyelesaikan sengketa hukum, dan

5. bahwa keputusan peradilan secara konsisten dilaksanakan.

\subsection{Konsep Perlindungan Hukum}

Konsep perlindungan hukum sangat erat kaitannya dengan konsep negara hukum dan juga konsep pengakuan dan perlindungan hak asasi

${ }^{11}$ Sentosa Sembiring, 2007, Hukum Investasi: Pembahasan Dilengkapi dengan Undang-Undang Nomor 25 Tahun 2007 Tentang Penanaman Modal, Nuansa Aulia, Bandung, hal. 39. 
manusia (HAM). Konsep pengakuan dan perlindungan terhadap hak-hak asasi manusia memberikan isinya dan konsep rechtstaat dan rule of law memberikan sarananya. ${ }^{12}$

Menurut oleh Phillipus M Hadjon;

prinsip perlindungan hukum bagi rakyat di Indonesia adalah prinsip pengakuan dan perlindungan terhadap harkat dan martabat manusia yang bersumber pada Pancasila dan prinsip-prinsip negara hukum Pancasila. $^{13}$

Dalam negara yang menganut prinsip negara hukum salah satu cirinya adalah adanya jaminan secara konstitusional terhadap hak-hak asasi manusia, dimana perlindungan hukum atas warga negara juga termasuk di dalamnya.

Pengertian perlindungan hukum, ada unsur perlindungan dan hukum, pertama-tama akan dibahas mengenai pengertian hukum, menurut Sudikno Mertokusumo hukum adalah;

12 Philipus M. Hadjon et.al., 2005, Pengantar Hukum Administrasi Indonesia (Introduction To The Indonesian Administration Law), Gadjah Mada University Press, Cetakan Kesembilan, Yogyakarta, hal. 20

${ }^{13}$ Ibid. keseluruhan kumpulan peraturanperaturan atau kaidah-kaidah dalam suatu kehidupan bersama, keseluruhan peraturan tentang tingkah laku dalam suatu kehidupan bersama yang dapat dipaksakan pelaksanaanya dengan suatu sanksi. ${ }^{14}$

Mengenai pengertian dari perlindungan menurut Poerwadarminta perlindungan berasal dari kata lindung, yang artinya; menempatkan sesuatu supaya tidak kelihatan, dan perlindungan adalah tempat berlindung atau merupakan perbuatan, tindakan atau hal melindungi. ${ }^{15}$ Jadi perlindungan hukum dalam hal ini suatu aturan yang menjamin agar suatu hubungan antara subyek hukum dengan subyek hukum lainnya dan atau obyek hukumnya berjalan berdasarkan peraturan dalam kehidupan bersama.

\section{Simpulan dan Saran}

\subsection{Simpulan}

1. Secara normatif Pasal 32 ayat (2) PP No. 24 Tahun 1997

14 Sudikno Mertokusumo, 1991, Mengenal Hukum, Liberty, Yogyakarta, hal. 37.

15 Poerwadarminta, W.J.S., Kamus Umum Bahasa Indonesia, Balai Pustaka, Cetakan Keenam, Jakarta, hal. 89. 
bertujuan

memberikan

kepastian hukum atas sertifikat hak milik atas tanah yang diterbitkan, yang usia penerbitannya lebih dari lima tahun. Namun dalam putusanputusan di PTUN, ketentuan tersebut tidak diperhatikan, hal ini karena sistem publikasi negatif yang dianut dalam sistem pendaftaran tanah di Indonesia, dimana hak dari pemilik yang sebenarnya sangat dilindungi yang juga tercermin dari rumusan Pasal tersebut yang tidak secara tegas menerapkan konsep rechtsverwerking, sehingga menimbulkan ketidakjelasan dalam rumusan pasal tersebut sehingga memungkinkan adanya tuntutan atas penerbitan sertifikat walau jangka waktu lima tahun terlewati. Sehingga Pasal 32 auat (2) PP No. 24 Tahun 1997 tersebut kurang memadai dalam memberikan kepastian hukum bagi pemegang sertifikat hak milik atas tanah.
2. Dengan kurang terjaminnya kepastian hukum, Pasal 32 ayat (2) PP No. 24 Tahun 1997 tidak cukup memberi perlindungan hukum bagi pemegang sertifikat hak milik atas tanah yang usia penerbitannya sertifikatnya lima tahun atau lebih. Sebab pelaksanaan haknya sebagai pemegang sertifikat hak milik masih dapat diganggu gugat oleh pihak lain yang merasa sebagai pemilik yang sebenarnya dari tanah tersebut.

\subsection{Saran}

1. Perlu pengaturan lebih lanjut untuk memperjelas kedudukan lembaga rechtsverwerking dalam hukum agraria sebagaimana terdapat dalam Pasal 32 ayat (2) PP No. 24 Tahun 1997 dalam suatu peraturan setingkat UndangUndang sehingga dapat menjamin kepastian hukum bagi pemegang sertifikat hak milik atas tanah. Dimana rumusannya pasalnya harus jelas menentukan batasan 
jangka waktu untuk melakukan keberatan atau gugatan.

2. Karena asas-asas, lembagalembaga hukum dan sistem hukum adat sebagai dasar pembentukan hukum agraria nasional, maka perlu penggunaan istilah yang bersifat Indonesia. Hal ini perlu agar masyarakat dan penegak hukum menyadari bahwa norma tersebut merupakan norma yang hidup dan berkembang dalam masyarakat hukum adat Indonesia. Sehingga hakim dalam memutus memiliki kesepakatan bahwa lembaga tersebut hidup dan berkembang dalam masyarakat hukum adat di Indonesia sehingga tidak ada alasan untuk tidak mengindahkannya. Dengan demikian perlindungan hukum bagi pemegang sertifikat hak milik atas tanah lebih terjamin.

\section{Daftar Pustaka}

\section{Buku}

Kartini Muljadi dan Gunawan Widjaja, 2004, Hak-Hak Atas Tanah, Prenada Media, Jakarta.

Kartini Kartono, 1996, Pengantar Metodologi Riset Sosial, Mandar Maju, Bandung.

Philipus M. Hadjon dan Tatiek Sri Djatmiati, 2009, Argumentasi Hukum, Gadjah Mada University Press, Cetakan Keempat.

Philipus M. Hadjon et.al., 2005, Pengantar Hukum Administrasi Indonesia (Introduction To The Indonesian Administration Law), Gadjah Mada University Press, Cetakan Kesembilan, Yogyakarta.

Poerwadarminta, W.J.S., Kamus Umum Bahasa Indonesia, Balai Pustaka, Cetakan Keenam, Jakarta.

Salim HS. H., 2008 , Perkembangan Hukum Jaminan di Indonesia, Rajawali Pers, Jakarta.

Sentosa Sembiring, 2007, Hukum Investasi: Pembahasan Dilengkapi dengan UndangUndang Nomor 25 Tahun 2007 Tentang Penanaman Modal, Nuansa Aulia, Bandung. 
Sudikno Mertokusumo, 1991, Mengenal Hukum, Liberty, Yogyakarta.

Willy Laluyan, et.al., 1982, Pertanahan Dalam Era Pembangunan Indonesia, Departemen Penerangan RI, Jakarta, hal. 18.

\section{Peraturan Perundang-Undangan}

Undang Undang Dasar Negara Republik Indonesia Tahun 1945.

Undang Undang No. 5 Tahun 1960 tentang Peraturan Dasar Pokok-Pokok Agraria..

Peraturan Pemerintah No. 10 Tahun 1961 jo. Peraturan Pemerintah No. 24 Tahun 1997 tentang Pendaftaran Tanah.

Peraturan Presiden No. 10 Tahun 2006 jo. Peraturan Presiden No. 85 Tahun 2012 tentang Badan Pertanahan Negara.

Keputusan Presiden No. 26 Tahun 1988 jo. Keputusan Presiden No. 154 Tahun 1999 tentang Badan Peretanahan Nasional.

Peraturan Menteri Negara Agraria / Kepala Badan Pertanahan Nasional Nomor 3 Tahun 1997 tentang Ketentuan Pelaksanaan Peraturan Pemerintah No. 24 Tahun 1997. 